\title{
A reconnaissance study of fluid inclusions in fracture-filling quartz and calcite from the Lopra-1/1 A well, Faroe Islands
}

\author{
Jens Konnerup-Madsen
}

\begin{abstract}
Fracture-filling calcite and quartz from the Lopra-1/1A well (at $2380 \mathrm{~m}$ and $3543 \mathrm{~m}$ depth) contains both aqueous low-salinity fluid inclusions and hydrocarbon-dominated fluid inclusions. Microthermometry indicates that the aqueous fluids contain 0.2 to 1.4 equivalent weight $\% \mathrm{NaCl}$ and occasionally contain traces of hydrocarbons. Homogenisation to liquid occurred between $90^{\circ} \mathrm{C}$ and $150^{\circ} \mathrm{C}$. Modelling based on these fluid inclusion observations indicates that during burial the basaltic section was subjected to temperatures of $160^{\circ} \mathrm{C}$ and $170^{\circ} \mathrm{C}$, occasional pressures of $600-700$ bars and the simultaneous percolation of aqueous and hydrocarbon fluids. These fluid conditions may also be relevant to the formation of zeolite observed in the Lopra-1/1A well.
\end{abstract}

Keywords: Basalts, Faroe Islands, fluid inclusions, hydrocarbons, veins, zeolites

Geological Institute, University of Copenhagen, Øster Voldgade 10, DK-1350 Copenhagen K., Denmark.

E-mail: jenskm@geol.ku.dk

Fluid inclusions in cements or minerals filling vugs and fractures in buried sedimentary and volcanic rocks may provide important information on the chemical and physical nature and origin of mineral-precipitating fluids, on the potential interplay between migrating hydrocarbon and aqueous fluids, and on the temperatures and pressures of precipitation (e.g. Bodnar 1990; Jensenius \& Burruss 1990). A reconnaissance study was undertaken of fluid inclusions in vug-and fracture-filling quartz and calcite from samples taken from the basalts penetrated by Lopra1/1A. The two samples studied are from core $1(2380 \mathrm{~m})$ and sidewall core $1(3543 \mathrm{~m})$. The fluid inclusions were examined by ordinary microscopy, fluorescence microscopy and with a Chaixmeca heating and freezing stage.

\section{Types and setting of fluid inclusions in selected samples}

The samples were selected by examining about 40 thin sections taken between $2204 \mathrm{~m}$ and $3543 \mathrm{~m}$ depth in the Lopra-1/1A well. Only two samples, from $2380 \mathrm{~m}$ and
$3543 \mathrm{~m}$ depth, were found to contain fracture-filling quartz and calcite with fluid inclusions suitable for further study.

Sample $2380 \mathrm{~m}$ (Lopra-1, core 1) is a sparsely plagioclase-glomerophyric olivine-clinopyroxene basalt with almost complete alteration of plagioclase and olivine. The quartz and calcite studied occur in mm-wide veins. The veins are rimmed by chlorite, calcite and quartz that appear to have been precipitated contemporaneously. According to Jørgensen (2006, this volume) the zeolites characterising this level in the core are laumontite, prehnite and pumpellyite.

Sample $3543 \mathrm{~m}$ (Lopra-1A, sidewall core 1) is a nearaphyric lapilli-tuff with extensively altered plagioclase, olivine and clinopyroxene phenocrysts in a cryptocrystalline groundmass. The irregular veins contain laumontite, prehnite, calcite and rare quartz. The veins are rimmed by chlorite. Again, calcite and quartz appear to have been precipitated contemporaneously, although quartz precipitation might have been slightly later. 


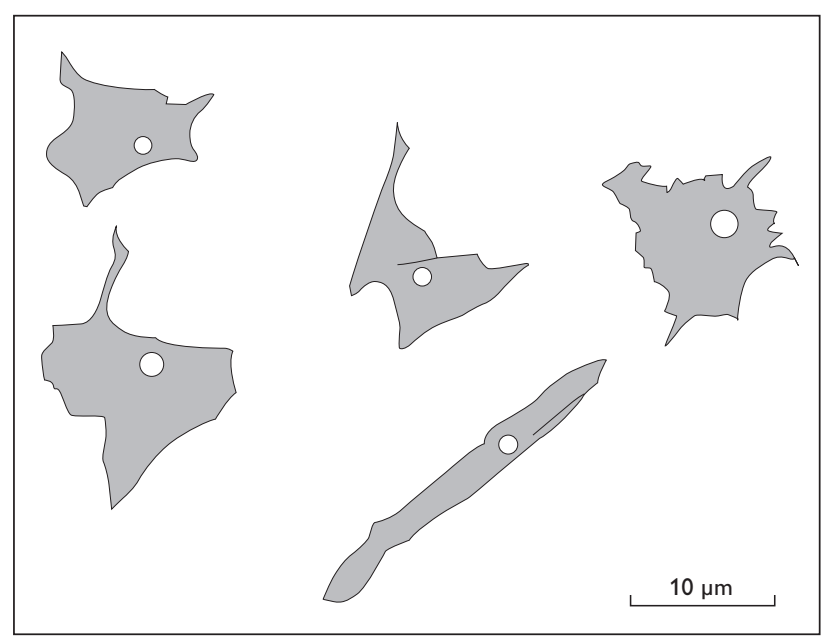

Fig. 1. Examples of typical morphologies of aqueous liquid-vapour fluid inclusions in quartz from core $1(2380 \mathrm{~m})$ from Lopra-1/1A.

\section{Types of fluid inclusions in quartz and calcite}

Two types of fluid inclusions were observed using fluorescence and ordinary light microscopy: (1) aqueous twophase (liquid-vapour) inclusions with about 5 vol.\% vapour at room temperature, and (2) one or two-phase hydrocarbon inclusions with fluorescence emission colours that vary from orange-yellow to green. With ordinary light microscopy it is difficult to distinguish between the twophase liquid-vapour hydrocarbon and aqueous inclusions, although the latter seem to be characterised by a (perhaps) slightly lower vol.\% vapour than the former. No clear relative chronology between the two fluid inclusion types could be established.

Examples of typical morphologies and phase proportions of fluid inclusions observed in quartz are shown in Fig. 1.

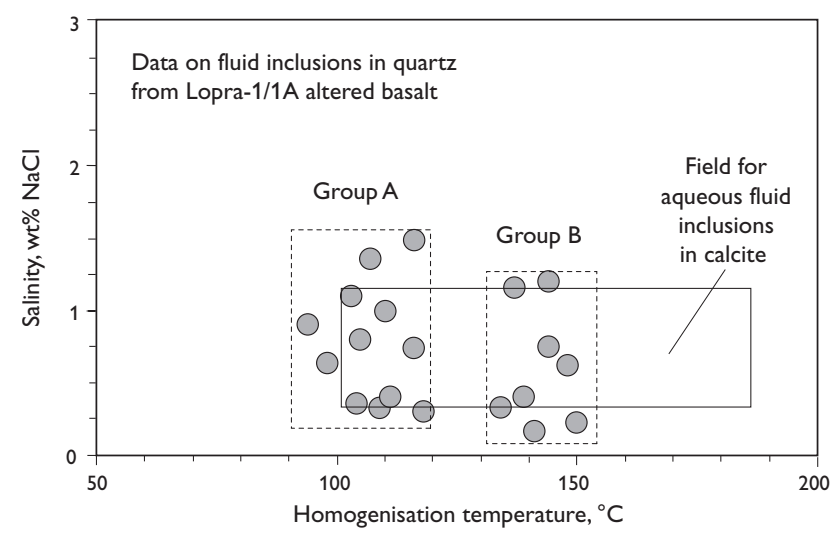

Fig. 2. Salinity versus liquid homogenisation temperatures of aqueous inclusions in quartz from Lopra-1/1A.
In general, the fluid inclusions are characterised by immature morphologies and occur in irregular groupings or in curved internal planar arrangements, suggesting periods for their entrapment which do not markedly postdate the growth of the host mineral. The liquid-vapour ratio in individual groupings varied slightly, most probably and mainly as a result of necking down of the inclusions after entrapment, because liquid-only inclusions could occasionally be observed together with the aqueous two-phase liquid-vapour inclusions. All inclusions indicative of having been influenced by necking down were avoided during the heating and freezing stage work.

\section{Microthermometry results on aqueous fluid inclusions}

The results of microthermometry of fluid inclusions in quartz and calcite are summarised in Fig. 2.

\section{Fluid inclusions in quartz}

Incipient melting of ice was observed at temperatures around $-32^{\circ} \mathrm{C}$, indicating the presence of additional ions such as $\mathrm{Ca}^{2+}, \mathrm{Mg}^{2+}$ and/or $\mathrm{Fe}^{2+}$ in solution rather than chlorides of $\mathrm{Na}^{+}$and/or $\mathrm{K}^{+}$(Konnerup-Madsen 1979). Final melting temperatures were observed in the range $-0.1^{\circ} \mathrm{C}$ to $-0.9^{\circ} \mathrm{C}$, corresponding to salinities from 0.167 to 1.49 equivalent weight $\% \mathrm{NaCl}$, respectively (average: 0.62 equivalent weight $\% \mathrm{NaCl}$ ) (Bodnar et al. 1989), but with no clear difference between the two samples. Temperatures of homogenisation occurred between $94^{\circ} \mathrm{C}$ and $150^{\circ} \mathrm{C}$ and bimodality in temperature is suggested from the data (see Fig. 2, groups A and B). Group A and group B inclusions gave average homogenisation temperatures of $108^{\circ} \mathrm{C}$ and $141^{\circ} \mathrm{C}$, respectively.

Group B inclusions in quartz showed in three cases clear indications (ragged outline of meniscus between vapour and liquid) of the formation of a clathrate hydrate after initial ice melting, indicating the presence of trace amounts of volatiles such as hydrocarbons in the entrapped group B fluids. However, although no temperature of dissolution of the hydrate could be obtained and hence the identity of the volatile component could not be established, its formation suggests that the higher temperatures of homogenisation obtained for group B inclusions may reflect trace concentrations of hydrocarbons in the vapour phase of these inclusions. 


\section{Fluid inclusions in calcite}

Only very few measurements were made on inclusions in calcite, as most inclusions occurred along well-defined healed fracture-planes so are secondary in origin. Final melting temperatures varied between $-0.2^{\circ} \mathrm{C}$ and $-0.7^{\circ} \mathrm{C}$, corresponding to salinities of 0.33 to 1.16 equivalent weight $\% \mathrm{NaCl}$. Homogenisation temperatures varied from $101^{\circ} \mathrm{C}$ to $186^{\circ} \mathrm{C}$ (Fig. 2). However, the higher homogenisation temperatures might conceivably reflect partial decrepitation (stretching) of the inclusions during heating (e.g. Bodnar \& Bethke 1984).

Two-phase (liquid-vapour) hydrocarbon inclusions were observed in fluorescence microscopy in both calcite and quartz. The abundance of hydrocarbon inclusions appears to be relatively higher in calcite and only very few were observed in quartz. The emission colours, from orangeyellow to green, may be interpreted roughly in terms of compositions corresponding to API gravities of 20-35 (Lang \& Gelfand 1985). No successful heating and cooling runs were, however, obtained on the hydrocarbon inclusions in the two samples.

\section{Interpretation of fluid inclusion data}

An interpretation in terms of pressures and temperatures for entrapment of the fluid inclusions in quartz is shown in Fig. 3.

Isochores corresponding to group A and B inclusions

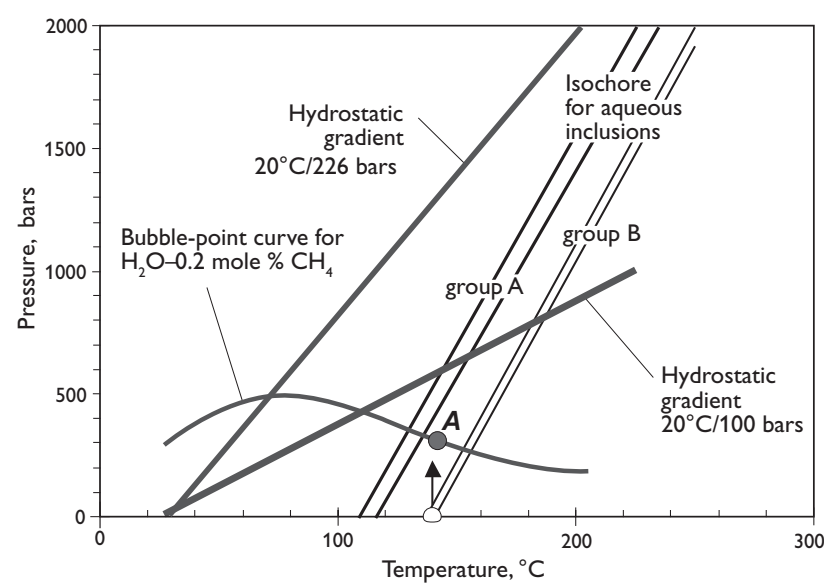

Fig. 3. Pressure-temperature diagram with isochores for groups A and $B$ inclusions in quartz from Lopra-1/1A. The open and filled circles show pressure and temperature at homogenisation for pure aqueous and aqueous- 0.2 mole $\% \mathrm{CH}_{4}$ fluids in group B inclusions, respectively. Bubble-point curve from Hanor (1980). See text for further comments.
(Brown 1989) in quartz are shown in Fig. 3, assuming them to be pure aqueous fluids with salinities as indicated by the final ice melting temperatures (Fig. 2). No indications of the entrapment of boiling aqueous fluids were observed during this study and the homogenisation temperatures for the fluid inclusions observed are thus considered to be minimum temperatures of fluid entrapment and host mineral formation. A comparison with geothermal gradients of $20^{\circ} \mathrm{C} / 100$ bars and $20^{\circ} \mathrm{C} / 226$ bars that are considered relevant for Lopra-1/1A and that reflect hydrostatic and lithostatic conditions, respectively, has been made in Fig. 3. If hydrostatic conditions prevailed, group $\mathrm{A}$ inclusions would indicate entrapment at around $140^{\circ} \mathrm{C}$ at pressures of around 600 bars.

Microthermometry indicated that Group B inclusions may contain traces of hydrocarbons and the isochores shown in Fig. 3 are therefore not strictly applicable because they assume an aqueous-only composition. As trace concentrations of hydrocarbons are present in group B inclusions, pressures at homogenisation will be considerably higher than indicated by the isochores drawn in Fig. 3 . The presence of only a few parts per thousand methane in solution would shift homogenisation pressures to values of 400-600 bars at the observed temperatures of homogenisation (Hanor 1980). The actual isochoric path for group $B$ inclusions should therefore be shifted to a setting essentially parallel to that shown but starting at the bubble-point curve for the actual aqueous-hydrocarbon system at around 400 bars (Fig. 3, point A). If this interpretation is valid, both groups of inclusions in quartz indicate minimum entrapment of fluids slightly different in composition at conditions of about 400 bars and $140^{\circ} \mathrm{C}$. Assuming hydrostatic conditions, probable entrapment of both group $\mathrm{A}$ and $\mathrm{B}$ aqueous fluids low in salts (average 0.61 equivalent weight $\% \mathrm{NaCl}$ ) and containing occasional traces of hydrocarbons occurred at around 600-700 bars at temperatures of $160^{\circ} \mathrm{C}$ to $170^{\circ} \mathrm{C}$. However, more data would be needed to substantiate this conclusion.

\section{Concluding remarks}

Although it is of a reconnaissance nature, the present study of fluid inclusions in fracture-filling quartz and calcite indicates that the basaltic sections represented by the samples examined were subjected to temperatures of $160^{\circ} \mathrm{C}$ to $170^{\circ} \mathrm{C}$ and pressures of $600-700$ bars at stages during their burial. During these burial conditions, precipitation of quartz and calcite in fractures (and vugs?) occurred in the presence of low-salinity aqueous fluids containing occasional traces of hydrocarbons. Similar P-T-fluid-char- 
acteristics may also be of relevance to the formation of e.g. zeolites in these rocks. Although no clear evidence for the simultaneous existence and migration of hydrocarbon and aqueous fluids was observed, such simultaneity is suggested by the occasional presence of hydrocarbons in the entrapped aqueous fluids and the hydrocarbon-dominated inclusions observed especially in calcite.

\section{References}

Bodnar, R.J. 1990: Petroleum migration in the Miocene Monterey Formation, California, USA: constraints from fluid-inclusion studies. Mineralogical Magazine 54, 295-304.

Bodnar, R.J. \& Bethke, P.M. 1984: Systematic stretching of fluid inclusions. Fluorite and sphalerite at one atmosphere confining pressure. Economic Geology 79, 141-146.

Bodnar, R.J., Sterner, S.M. \& Hall, D.L. 1989: SALTY: a FORTRAN program to calculate compositions of fluid inclusions in the system $\mathrm{NaCl}-\mathrm{KCl}-\mathrm{H}_{2} \mathrm{O}$. Computers \& Geosciences 15 , 19-41.

Brown, P.E. 1989: FLINCOR: a microcomputer program for the reduction and investigation of fluid inclusion data. American Mineralogist 74, 1390-1393.

Hanor, J.S. 1980: Dissolved methane in sedimentary brines: potential effect on the PVT properties of fluid inclusions. Economic Geology 75, 603-617.

Jensenius, J. \& Burruss, R.C. 1990: Hydrocarbon-water interactions during brine migration: Evidence from the composition of hydrocarbon inclusions in calcite from Danish North Sea oil fields. Geochemica Cosmochemica Acta 54, 705-713.

Jørgensen, O. 2006: The regional distribution of zeolites in the basalts of the Faroe Islands and the significance of zeolites as palaeotemperature indicators. Geological Survey of Denmark and Greenland Bulletin 9, 123-156 (this volume).

Konnerup-Madsen, J. 1979: Fluid inclusions in quartz from deepseated granitic intrusions, south Norway. Lithos 12, 13-23.

Lang, W.H. \& Gelfand, J.C. 1985: The evaluation of shallow potential in a deep field wildcat. Log Analyst 26, 13-22.

Manuscipt received 15 December 1999; revision accepted 29 June 2001. 